\title{
Et helsevesen for alle
}

\author{
Det viktigste helsepolitiske temaet er ikke mulig å skrelle ned til ett viktig område, da helsepolitikken henger \\ sammen i en kjede fra vugge til grav.
}

For Fremskrittspartiet er det derfor viktig å snakke om helse i sin helhet. Når barn blir sett og hørt, og blir gitt mulighet til å leve trygge og gode liv som gir dem mulighet til å mestre, bygger vi sterke mennesker med dertil hørende bedre helse. Derfor er helsestasjoner, barnehage, skole og nærmiljø viktige arenaer, og derfor er lavterskeltilbud og et forebyggende barnevern viktig.

Å skape et samfunn som gir folk trygghet og valgfrihet til å ta gode valg for seg og sine, må ligge i bunn for alt vi gjør. Av den grunn skal vi ha gode tilbud og oppfølging for dem som sliter, eller som har ekstra utfordringer i forhold til å leve sine gode liv.

\section{Ventetider koster}

Når sykdom og skade oppstår, skal folk vite at hjelpen er der. I Norge har vi gode velferdsordninger, rettigheter og muligheter, og et godt helsevesen med gode medarbeidere som hver dag står på, redder liv og utfører mirakler.

Men vi har også en del utfordringer som ikke hadde behøvd å være der. Vi har bygd opp et system som gir god hjelp når akutt skade eller sykdom inntreffer. $70 \%$ av alle innleggelser handler om akutt hjelp. For alle de andre er systemet preget av ventetider og til dels problemer med å finne frem i systemet. Det betyr at noen venter altfor lenge, og det betyr at noen får hjelp som nødvendigvis ikke er den rette hjelpen. Særlig innen rus, psykiatri og rehabilitering er det nødvendig med en spissing av tilbudet. Vi må bli flinkere til å gi riktig hjelp, i riktig mengde til rett tid. Dette vil gi bedre resultat, samtidig som vi unngår å «sløse» med ressursene.

Sykehusenes organisering må gjennomgås. Fremskrittspartiet vil ha en nasjonal sykehusplan som ser på helheten av tilbudet over hele landet, sett i dag og på lang sikt. Hvor er ventetidene lengst, hvor er tilbudene for dårlige, hvor skal spesialisering foregå, hvilke sykehus må bygges ut/ pusses opp, og hvor må medisinskteknisk utstyr oppgraderes, er spørsmål som må besvares.

Innen dagens rammer kan mye gjøres på en bedre måte for å få mest mulig ut av de bevilgningene som blir gitt. Det er også kjent at ventetider koster store beløp. Ved å få ned ventetider frigjør vi penger til å behandle enda flere, som igjen får ned ventetider ytterligere. Ventetider har også det ødeleggende i seg at man skaper frykt

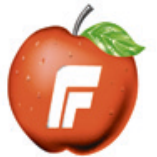 \\ Fremskrittspartiet}

og i verste fall ytterligere skade eller forverring av sykdomsbildet. Derfor vil ikke Fremskrittspartiet akseptere lange ventetider. I en overgangsperiode vil dette måtte bety økte bevilgninger. $\AA$ «reparere» mennesker koster penger, enten det skjer i dag eller neste år.

\section{Mennesker foran system}

Det finnes mye ledig kapasitet både innenfor det offentlige og det private helsevesenet og i utlandet. Hvis vi i tillegg øker bruken av avtalespesialistene, vil vi fort kunne få ned tallet på antall mennesker som står i kø. Siden det er viktig for Fremskrittspartiet å ha et trygt og godt offentlig helsetilbud, er det helt avgjørende for oss at ekstra midler blir bevilget, slik at bruk av andre tjenesteleverandører ikke går på bekostning av de offentlige sykehusene.

I tillegg til at vi ønsker å dele budsjettet $i$ to, ved å skille mellom drift og investering, vil vi legge ned de regionale helseforetakene. For å unngå at folk blir «kasteballer» i systemet, særlig når det gjelder eldre, psykisk syke, rusavhengige og folk under rehabilitering, vil vi ha et finansieringssystem som setter mennesker foran system.

I mange debatter blir ord som brukermedvirkning, individuell plan, sømløse behandlingsløp og tilrettelegging, ofte brukt. Virkeligheten er for veldig mange milevis fra dette. Særlig for de aller sykeste og, enda verre, for dem som mangler sterke pårørende. De som «skriker høyest», får mest og best hjelp, og slike forskjeller vil Fremskrittspartiet bekjempe. Alle skal ha trygghet for at de får riktig og god behandling innen fornuftig tid.

Helseministre har kommet og gått de siste årene. Men en ting har de hatt felles. De har hatt et problem med å erkjenne mangler, de har hatt liten vilje til endring, og det egentlige ansvaret har de ikke tatt. Å skylde på de regionale helseforetakene eller kommunene gir ingen endring, og dette ønsker Fremskrittspartiet å gjøre noe med.

\section{Kari Kjønaas Kjos}

kari-kjonaas.kjos@stortinget.no

Kari Kjønaas Kjos (f. 1962) er stortingspolitiker for Fremskrittspartiet og medlem av Helseog omsorgskomiteen på Stortinget.

Mottatt 7.6.2013 og godkjent 27.6.2013. Medisinsk redaktør Hanne Støre Valeur. 